\title{
KONTESTASI YANG SETEMPAT DAN YANG PENDATANG PADA ARSITEKTUR MASJID NUSANTARA: \\ Jelajah atas Masjid Ampel Surabaya dan Masjid Jami’ Malang
}

\author{
Achmad Gat Gautama \\ Fakultas Sains dan Teknologi Jurusan Teknik Arsitektur UIN Maulana Malik Ibrahim Malang. \\ Jalan Gajayana No. 50 Malang. Telp.08155502176. e-mail: gatgautama@gmail.com
}

Abstract

Conservation on architecture plays very important role in shaping the identity or memory of a place as well as presenting its current context. There are must be three strategies consisting in conservation, those are: continuity, development, and usage. Continuity shows the establishment on the tradition for the sake of the continuity on the building identity in the present and future time. Development is a process of changing and adjusting toward the current of a building to gain the best condition. Usage is creating the use or giving the facility for the existance sustainability of old, present, and future building. Through the tracing on two architure cases, Masjid Sunan Ampel and Masjid Jami' Malang, this paper aims to explore the character of architecture identity of mosque in Indonesia as an alternative of architecture sustainability which is relevant to Indonesian context, and to the development of technology as one of the instrument to build. The initial stage is exploring the architec of two mosques by using three conservation strategies as the reading tool. The next stage is doing an interpretaive analysis by comparing the finding character identity both mosques' identity in dialogic way. The above study presents the 
two character of Indonesain mosques' achitecture which includes technology in the building process. These characters have been becoming the starting planning strategy of mosque's architecture which orientates to Indonesian context as well as creatively and innovatively.

Key words: conservation, character identity, contextual planning strategy

\section{Pendahuluan}

Dalam tradisi lisan dan tertulis, semenjak agama Islam menanamkan pengaruhnya di Nusantara. Masjid Demak dianggap masjid Jamik pertama di Nusantara yang dibangun oleh para wali. Bentuknya mengacu pada tradisi lokal non-Islam yang telah ada sebelumnya, yang berupa atap piramida bersusun yang ditopang empat sakagurunya dan juga ruang serambi (Khan, 1994: 35). Karena itulah, tidak salah jika masjid ini bisa dijadikan titik pijak yang menginspirasikan perkembangan arsitektur masjid Nusantara di masa selanjutnya. Dengan mengacu pada kelokalan, masjid ini bukanlah monumen yang memberikan identitas Islam "universal" kepada komunitas muslim setempat.

Dalam perkembangan sejarah selanjutnya, bermunculan sejumlah masjid tipe "Demakan" (Javanese Vernacular) di seluruh pelosok Nusantara. Masjid dengan tipe ini pada umumnya memiliki wujud yang mengambil acuan dasar Masjid Demak sebagai faktor keajegan (continuity) yang telah mengalami pemalihan sebagai faktor perubahan (change)-nya.

Masjid Ampel Surabaya dan Masjid Jami' Malang adalah dua contoh yang mengambil keajegan atap piramida bersusun dengan beberapa pemalihan sesuai dengan karakter tempat dan zaman saat membangunnya. Dalam perkembangan yang mutakhir, kedua masjid ini adalah contoh hasil konservasi arsitektural yang mendasarkan perwujudannya pada keberlanjutan rancangan yang berwawasan Nusantara. Konservasi arsitektur memegang peranan penting dalam menciptakan identitas atau memori suatu kawasan sekaligus menghadirkan konteks kekiniannya (Budihardjo, 2004: 27). Ada tiga strategi yang harus ada dalam konservasi, yaitu: pengajegan, pengembangan, dan pemanfaatan (Hatmoko, 1999: 45). Pengajegan menunjukkan pengakaran pada tradisi setempat demi keberlanjutan identitas bangunan di masa kini dan mendatang. Pengembangan adalah proses perubahan dan penyesuaian dengan kekinian dari suatu bangunan (wujud perlanggaman dan teknologi konstruksi) untuk mendapatkan kondisi terbaik. Pemanfaatan adalah men- 
ciptakan kegunaan atau memberi wadah bagi kegiatan demi keberlangsungan eksistensi bangunan lama di masa kini dan mendatang. Permasalahannya adalah, apakah kedua corak konservasi kedua arsitektur masjid di atas masih merujuk pada arsitektur Nusantara di mana di satu sisi tetap mempertahankan unsur yang setempat dan di sisi lain mengadopsi unsur-unsur yang pendatang? Apakah penyandingan kedua unsur (yang setempat dan yang pendatang) ini dalam wujud baru bisa selaras dan terpadu?

Tulisan ini berupaya mengungkapkan karakter identitas arsitektur masjid Nusantara melalui jelajah masjid Ampel Surabaya dan Jami' Malang sebagai alternatif keberlanjutan arsitektur yang berwawasan Nusantara. Sasaran yang dicapai adalah bahwa karakter identitas kedua contoh ini bisa dijadikan titik berangkat strategi perancangan arsitektur masjid yang menusantara sekaligus bersifat kreatif dan inovatif.

\section{Genealogi Arsitektur Masjid}

\section{Masjid Ampel Surabaya}

Masjid ini dibangun oleh Sunan Ampel, salah seorang walisongo senior pada tahun 1450 M. Penampilan masjid sekarang adalah hasil beberapa kali perluasan dan renovasi yang dimulai pada era kolonial hingga kemerdekaan di akhir abad XX. Lihat Gambar 1 dan 2.

Bangunan masjid lama masih mengacu pada tipe Demakan, berdenah bujursangkar, dimana di dalamnya terdapat empat sakaguru dari kayu jati yang menyangga atap tajug bersusun dua. Di dalam bangunan induk ini juga terdapat menara dengan puncak yang beratap kerucut. Di sekeliling bangunan induk ini terdapat serambi. Langgam Demakan pada masjid lama ini juga dipadukan dengan langgam Indische Empire, yang tertampilkan pada unsur dinding tebal dan pintu dengan unsur lengkung di bagian atasnya. Langgam ini sangat populer pada masa kolonial saat bangunan direnovasi dan diperluas.

Bangunan perluasan masjid terletak di sebelah utara dan masjid baru terletak di sebelah barat laut masjid lama. Renovasi terbesar dan menyeluruh dilaksanakan pada tahun 1990-an dengan melakukan penataan seluruh kompleks masjid dan penambahan beberapa bangunan. Pada bagian perluasan masjid ditampilkan perpaduan antara langgam setempat, seperti atap tajug, dengan unsur pendatang berlanggam modern dan Pan Islamic, seperti komposisi geometri dan arabesk. Atap masjid baru menunjukkan perpaduan antara langgam setempat dan langgam pendatang, seperti atap tajug yang menyisakan rusuk-rusuk pada bagian puncaknya dan kubah yang berada di dalamnya (Santoso, 1999: 65). 


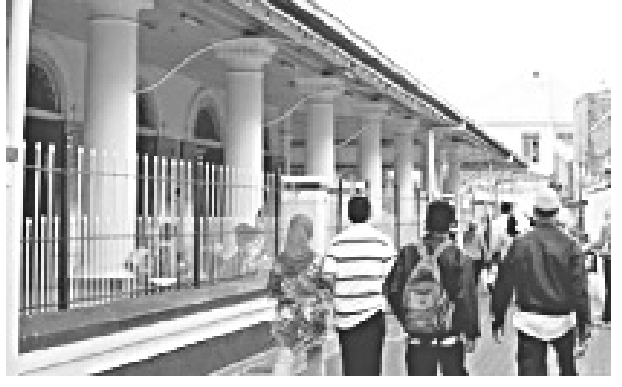

1

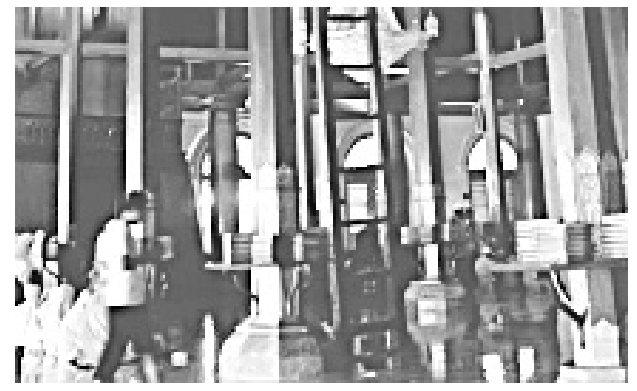

2

Gambar 1. Bangunan masjid Ampel lama, memiliki kombinasi langgam Jawa dengan seperti yang ditunjukkan oleh kolom besar dan pintu yang lebar.

Gambar 2. Ruang dalam masjid Ampel lama yang didominasi unsur struktur kayu (Sumber: dokumen pribadi)

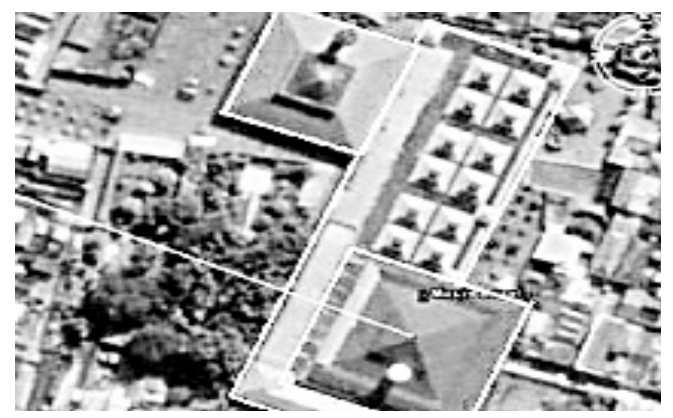

Gambar 3. Site Plan Masjid Ampel. Masjid lama beratap hijau, sedangkan bangunan tambahan dan masjid baru beratap merah (Sumber: google image, www.google.co.id)

2. Masjid Jami' Malang

Masjid ini didirikan pada tahun 1853, berdenah bujursangkar dengan serambi di sekelilingnya. Tahun 1890 dibangun bangunan tambahan di sebelah barat masjid lama, sehingga ruang mihrab masjid lama dipindah ke bangunan baru. Antara tahun 1920 sampai 1930, di timur bangunan lama dibangun sebuah serambi bergaya klasik lokal beratap sosoran yang dilengkapi sepasang menara pendek berketinggian dua lantai yang berdenah segi delapan.

Setelah era kemerdekaan, di tahun 1950-an masjid mengalami perluasan. Saat itu diadakan perubahan pada serambi menjadi bangunan berlanggam Timur Tengah (Pan Islamic), dengan diberi penampil gerbang beratap kubah dan atap dak beton. Menara pun mengalami perubahan bentuk menjadi lebih langsing, tinggi dan dengan atap kubah. Unsur-unsur arsitektural seperti 
bentuk busur, kubah, dan menara pada masa itu dianggap mewakili "identitas universal” arsitektur, lihat gambar 5.

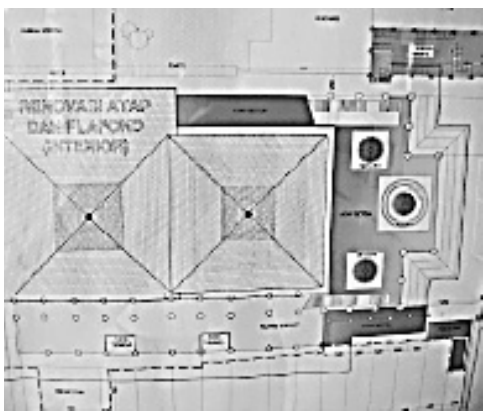

4

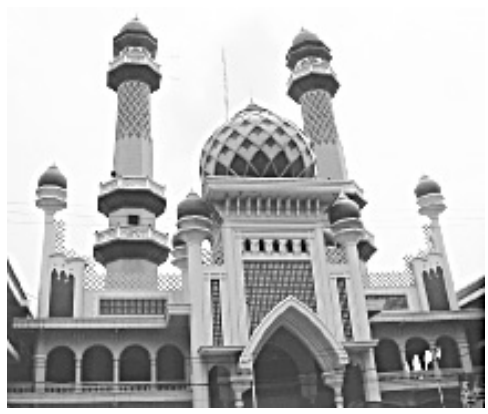

5

Gambar 4. Site Plan Masjid Jami' Malang. Bangunan utama masjid beratap hijau dan bagian serambi timur dilengkapi atap kubah yang diapit dua menara (Sumber: gambar kerja renovasi masjid, 2004).

Gambar 5. Gerbang dan menara beratap Kubah dan busur lengkung pada main entrancenya dianggap mewakili "identitas universal” arsitektur Islam (Sumber: Dokumen Pribadi)

Bangunan masjid Jami' Malang ini terdiri dari tiga massa bangunan yang berderet dengan orientasi barat-timur. Bangunan yang letaknya paling barat, beratap tajug bertumpang dua, adalah bangunan perluasan yang dibangun di masa Hindia Belanda tahun 1890. Bangunan di sebelah timurnya adalah bangunan masjid awal, yang berlanggam dan berkonstruksi setempat, beratap tajug tumpang tiga yang dibangun tahun 1853 . Sedangkan serambi depan yang terletak paling timur, pada mulanya dibangun di tahun 1950-an beratap kubah, dan di tahun 1999 ditambahkan lantai mezanin yang dinaungi kubah. Lihat gambar 6.

Ruang dalam masjid merupakan gabungan dari dua bangunan yang dibangun pada masa yang berbeda. Ruang bagian barat diatapi tajug yang berstruktur cukup modern: empat sakaguru yang menopang kuda-kuda yang disambung dengan sistem klem (sambungan yang memakai gabungan plat baja) yang menghasilkan ruang yang luas di antara keempat sakaguru kayu. Sementara ruang bagian belakang, struktur atapnya masih tradisional, memakai empat sakaguru dan enam belas sakarewa yang disambung dengan sistem purus. 


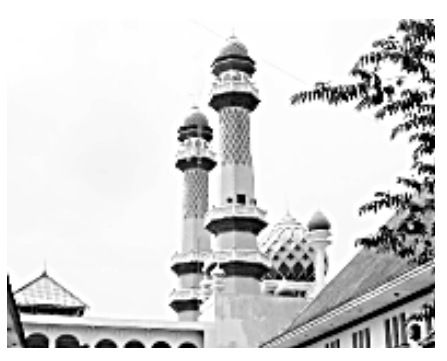

6

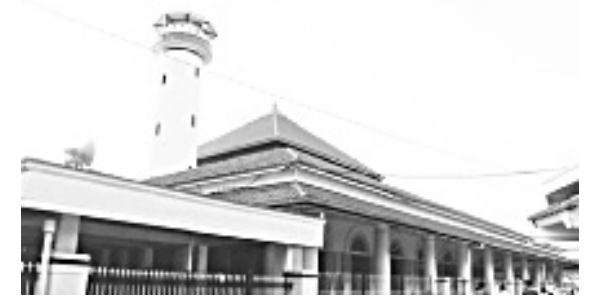

7

Gambar 6. Keberadaan atap tajug semakin tenggelam oleh dominasi atap dan menara berkubah. Gambar 7. Masjid lama Ampel yang menunjukkan adanya kombinasi antara unsur berlanggam Nusantara (Jawa) dengan unsur berlanggam Indische Empire (Sumber: dokumen pribadi)

\section{Jelajah Rancangan Masjid}

\section{Masjid Ampel Surabaya}

Secara visual, tampilan keseluruhan kompleks masjid Ampel menunjukkan adanya kombinasi antara unsur-unsur yang setempat dan unsur-unsur yang pendatang, yang lama dan yang baru tanpa harus menghapuskan atau mengabaikan salah satu unsur. Masjid ini menunjukkan diri sebagai arsitektur masjid Nusantara, beratap tajug, berlanggam Jawa yang menerima dan memadukan dirinya dengan unsur yang pendatang, seperti langgam Indische Empire, langgam Pan Islamic (kubah, busur, geometri, arabesk) dan sentuhan konstruksi modern.

Upaya konservasi masjid lama dilakukan dengan mempertahankan keasliannya seperti pada masa perluasan dan renovasi masjid di era kolonial. Unsur dinding yang melingkupi ruang dalam masjid mengacu pada langgam Indische Empire, berupa tembok masif dengan beberapa pintu berjalusi kayu yang berventilasi lengkung berteralis di atasnya. Ruang dalam masjid lama ini memiliki suasana terpusat, terlindungi atau terlingkupi, karena keberadaan dinding masif dan pintu berjalusi yang berkesan kokoh dan tegar. Dengan demikian, masjid lama ini menunjukkan adanya kombinasi antara unsur berlanggam Nusantara (Jawa) dengan unsur berlanggam Indische Empire yang populer di era kolonial.

Bangunan hasil perluasan di sebelah utara dan masjid baru di sebelah barat laut menunjukkan adanya kombinasi antara unsur-unsur yang setempat dan unsur-unsur yang pendatang. Langgam masjid Nusantara, yang berupa atap tajug yang disangga oleh empat kolom sakaguru diserentakkan kehadirannya 
dengan langgam Pan Islamic, yang berupa unsur kubah, arabesk, geometri dan busur. Pada masjid baru terlihat upaya menggabungkan unsur tajug dengan unsur kubah yang dimanifestasikan pada atap kubah yang "dikurung" oleh batang-batang rusuk yang berwujud tajug.

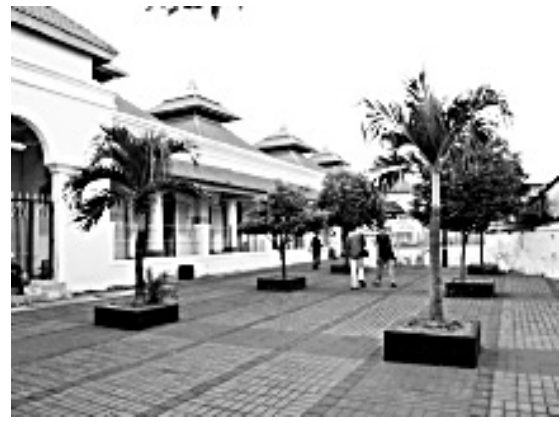

8

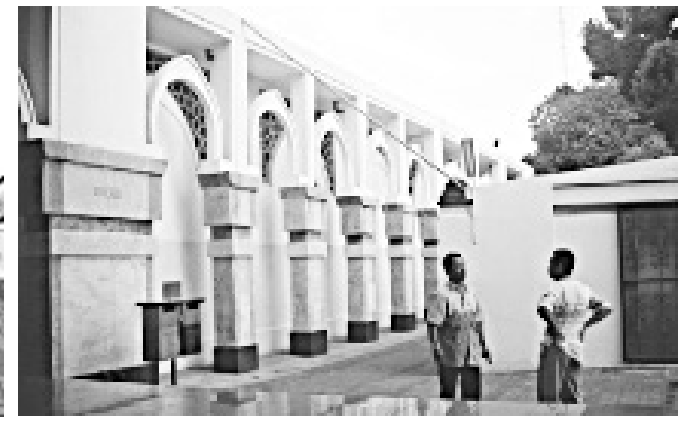

9

Gambar 8. Bangunan perluasan masjid, mengacu pada langgam masa lalu yang dipadukan dengan langgam masa kini.

Gambar 9. Salah satu sisi masjid baru yang menggunakan langgam Pan Islamic yang dipadukan dengan konteks kekiniannya (Sumber: dokumen pribadi)

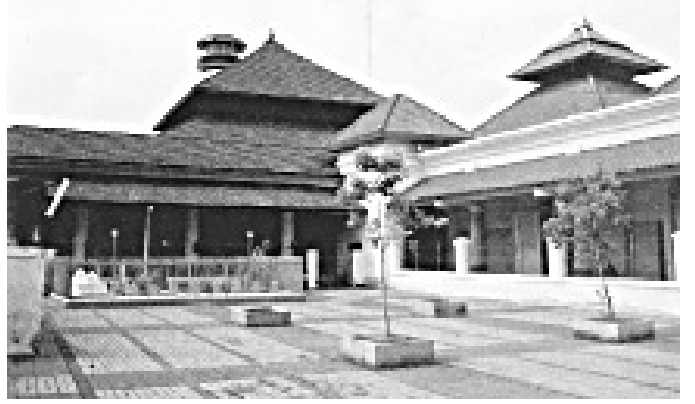

10

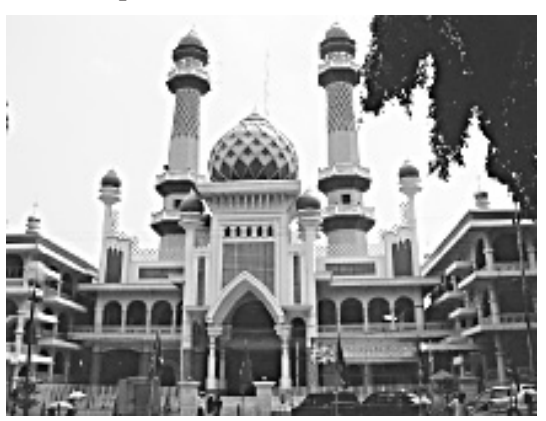

11

Gambar 10. Penyandingan yang selaras antara masjid Ampel lama dengan bangunan tambahannya.

Gambar 11. Tampilan visual fasad masjid Jami' Malang yang menawarkan "identitas universal” arsitektur Islam (Sumber: dokumen pribadi)

Secara fungsional, kegiatan ibadah masih menggunakan masjid lama yang masih bisa menunjukkan suasana sakral dan historis. Jika kegiatan peribadahan dilakukan orang dalam jumlah banyak, pusat aktivitas yang berupa mihrab bergeser ke masjid baru. Lihat gambar 9.

Dengan mengamati keseluruhan tampilan masjid, terlihat penyatuan antara masjid lama, perluasan masjid, dan masjid baru yang terpadu dan 
selaras. Bangunan masjid lama yang berlanggam gabungan Jawa-Indische Empire diserentakkan kehadirannya dengan bangunan perluasan dan masjid baru yang berlanggam gabungan Jawa-Pan Islamic. Adanya dominasi gaya arsitektur Jawa pada bangunan lama dan bangunan baru, menjadikan langgam Jawa sebagai unsur pengikat keseluruhan bangunan. Dengan kata lain, unsur kejawaan melebur pada bangunan lama dan baru. Masjid lama tetap mempertahankan keasliannya, sedangkan bangunan perluasan beserta masjid baru berupaya menggapai kekiniannya dengan mengakomodasi unsur kemodernan dan unsur universalitas Islam. Meski begitu, keduanya adalah satu-kesatuan yang melebur pada satu identitas: arsitektur masjid Nusantara. Teknologi konstruksi baru, seperti sistem bangunan bentang lebar, disandingkan dengan teknologi yang sudah ada sebelumnya, seperti sistem dinding pemikul dan pemakaian empat sakaguru beserta beberapa sakarewa yang disambung dengan sistem purus, lihat gambar 10 .

\section{Masjid Jami' Malang}

Secara visual, tampilan fasad bagian depan masjid Jami' Malang merujuk pada hasil renovasi di tahun 1950-an yang mengedepankan langgam Pan Islamic berupa penonjolan bentuk busur lengkung pada ambang pintu, ornamen geometri dan atap kubah. Unsur-unsur arsitektural di atas hingga saat ini masih dianggap mewakili "identitas universal" arsitektur Islam, sebagaimana diyakini oleh banyak orang.

Secara keseluruhan, masjid ini bisa dilihat sebagai arsitektur masjid Nusantara (yang setempat) berlanggam Jawa yang dibungkus atau "ditopengi" oleh selubung arsitektur masjid berlanggam Pan Islamic sebagai identitas universal Islam (yang pendatang). Jadi bisa dikatakan adanya penempelan antara langgam Jawa (yang setempat) di satu sisi dengan langgam Pan Islamic (yang pendatang) di sisi yang lain, dan bukan peleburan, lihat gambar 12.

Ruang utama berupa ruang dalam masjid, tempat utama peribadahan shalat atau khotbah yang dilingkupi oleh dinding berpintu banyak, berlanggam Jawa, memiliki sifat sakral, tertutup, dan dapat dikategorikan sebagai arsitektur perlindungan. Sedangkan ruang tambahan berupa serambi dan mezanin di lantai atasnya, berfungsi sebagai tempat kegiatan sosial masjid dan limpahan kegiatan peribadahan di dalam masjid, berlanggam Pan Islamic, memiliki sifat profan, terbuka, dan bisa dikategorikan sebagai arsitektur perteduhan. Kedua jenis ruang ini dipisahkan oleh unsur pemisah berupa dinding berpintu banyak, berlanggam Indische Empire, yang juga 
berfungsi sebagai penghubung antara ruang luar dan ruang dalam, ruang sakral dan ruang profan, lihat gambar 13 .

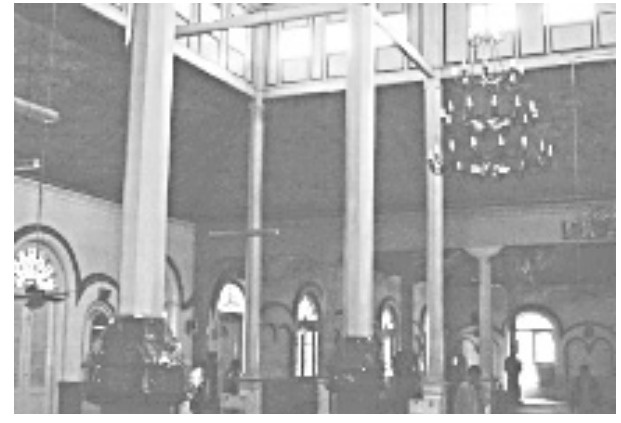

12

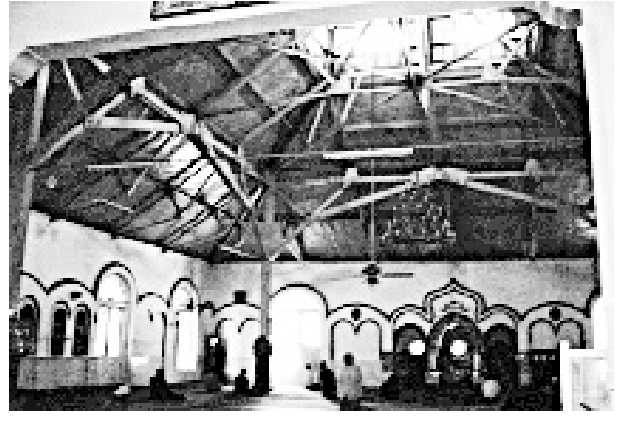

13

Gambar. 12. Ruang dalam masjid Jami' Malang, memakai empat sakaguru dan enam belas sakarewa yang disambung dengan sistem purus.

Gambar 13. Ruang dalam masjid sebelah barat, menempatkan empat sakaguru yang menopang kuda-kuda yang disambung dengan sistem klem yang menghasilkan ruang yang luas di antara keempat sakaguru kayu (Sumber: dokumen pribadi)

Dari penjelasan di atas dapat ditunjukkan bahwa ruang utama masjid yang berlanggam Jawa (yang setempat) tidak diserentakkan kehadirannya dengan ruang serambi dan mezanin masjid yang berlanggam Pan Islamic. Unsur dinding berpintu banyak yang berlanggam Indische Empire difungsikan sebagai unsur penyekat atau pemisah kedua ruang tadi yang memang sengaja tidak disandingkan.

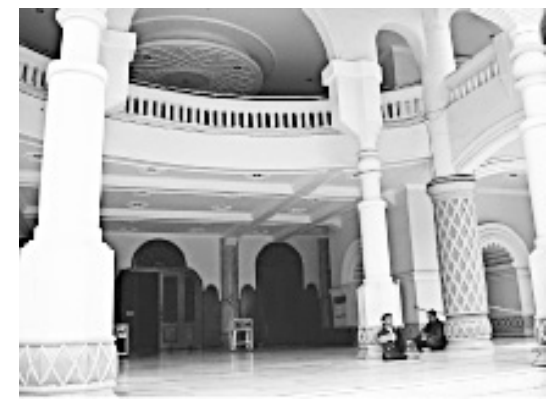

Gambar 14. Tampilan serambi masjid dan lantai mezanin di atasnya berkesan profane dan mewah (Sumber: dokumen pribadi)

Dengan demikian, hasil konservasi rancangan masjid ini memiliki pemaknaan identitas langgam yang ambigu. Langgam Jawa yang tertampilkan pada bangunan utama masjid beserta atap tumpang tajugnya bisa dilihat sebagai unsur arsitektur utama yang diletakkan di ranah yang bersifat sakral. 
Pada ruang dalam khas Jawa yang ditunjukkan oleh unsur saka guru, suasana tertutup, tenang, hening, dilingkupi oleh dinding dan kemiringan atap tajug. Sementara, jika dilihat dari luar, masjid ini secara visual menampakkan wujud langgam Pan Islamic yang dominan, dan nyaris tak terlihat langgam Jawa yang diselubunginya. Jika kita berada di ruang dalam masjid, kita merasakan berada di ruang yang beridentitas Jawa. Sementara jika kita berada di serambi masjid, kita merasakan identitas ruang Timur Tengah.

Unsur dinding beserta pintu berjalusi yang berlanggam Indische Empire di kedua sisinya (sisi dalam dan sisi luar bangunan) menunjukkan perpaduan yang selaras dan menyatu dengan kedua ruang yang dipisahkannya. Pada ranah ruang dalam masjid yang berlanggam Jawa, keberadaan dinding beserta pintu berjalusi ini menunjukkan keterpaduannya dengan semakin mengokohkan identitas Jawa yang lebih kaya. Sebaliknya, di ranah serambi, identitas Pan Islamic menunjukkan dominasi yang kuat karena keterpaduannya dengan dinding dan pintu ini yang mencitrakan kemegahan.

\section{Kajian Kritis}

1. Masjid Ampel Surabaya

Masjid Ampel Surabaya menunjukkan adanya dominasi langgam Jawa (yang setempat) yang dikombinasikan dengan langgam Indische Empire dan langgam Pan Islamic (yang pendatang). Bangunan masjid lama dan bangunan perluasan menunjukkan kombinasi antara langgam Jawa, berupa atap tajug bersusun dua yang disangga oleh empat sakaguru, dengan langgam Indische Empire, berupa dinding pemikul masif tebal, kolom luar yang tebal meruncing ke atas, dan beberapa pintu berjalusi kayu dengan lubang ventilasi lengkung di atasnya. Bangunan masjid baru menunjukkan kombinasi antara langgam Jawa, berupa batang-batang rusuk berwujud tajug pada puncak bangunan, dengan langgan Pan Islamic, berupa kubah yang dikurung tajug yang berupa rusuk tadi dan unsur geometri arabesk serta busur lancip di sepanjang dindingnya. Masjid lama beserta bangunan perluasannya dipersandingkan dengan masjid baru secara selaras yang secara dominan langgam Jawa dijadikan sebagai unsur pengikat kompleks masjid ini.

Mengingat bangunan ini bernilai sejarah dan berkarakter arsitektur tinggi, maka titik tolak tindakan konservasinya adalah memelihara dan melestarikan sesuai kondisi bangunan dan lingkungan yang bersangkutan dari kerusakan. Konservasi dilakukan dengan merujuk pada kondisi seperti aslinya, dengan tingkat perubahan kecil. Dalam perkembangannya, bangunan perluasan 
ini mengalami kemunduran (degradasi) fungsi. Pengembangan arsitektur berupaya mengembalikan atau memulihkan kondisi dan melengkapi sarana dan prasarana yang kurang. Konservasi dilakukan dengan merujuk pada kondisi aslinya, agar dapat berfungsi sebagaimana mestinya, serta melakukan penyesuaian terhadap tuntutan kegunaan baru, dengan tingkat perubahan sedang. Penambahan rancangan masjid Ampel baru pada sisi barat laut masjid lama dilakukan karena adanya kebutuhan ruang yang lebih luas di kawasan cagar budaya (Masjid Ampel lama beserta perluasannya). Penambahan berupaya mengabstraksikan pola bentuk yang mengacu pada bangunan yang sudah ada, sehingga bangunan baru ini dapat menunjang karakter kawasan.

\section{Masjid Jami' Malang}

Masjid Jami' Malang menunjukkan adanya keterpisahan secara tegas antara langgam Jawa pada ruang dalamnya dengan langgam Pan Islamic pada ruang luarnya. Sehingga secara visual masjid ini merupakan masjid Jawa yang diselubungi atau ditopengi oleh fasad yang bercitra Timur Tengah. Dinding masif beserta pintu berjalusi berlanggam Indische Empire menjadi unsur pemisah antara kedua ruang tadi. Adanya kombinasi antara dinding dan pintu berjalusi yang berlanggam Indische Empire dengan ruang dalam yang berlanggam Jawa dan ruang luar yang berlanggam Pan Islamic, semakin menegaskan fungsi dinding masif ini sebagai penyelaras antara ruang dalam dan ruang luar yang berbeda karakternya masing-masing.

Mengingat bangunan ini bersejarah dan bernilai arsitektur tinggi, maka titik tolak tindakan konservasinya adalah memelihara dan melestarikan sesuai kondisi bangunan dan lingkungan yang bersangkutan dari kerusakan. Konservasi dilakukan dengan merujuk pada kondisi seperti aslinya, dengan tingkat perubahan kecil. Konservasi pada fasad masjid mengacu pada perluasan bagian serambi di tahun 1950-an, dengan perubahan tampilan menjadi bangunan berlanggam timur tengah (Pan Islamic), dengan diberi penampil gerbang beratap kubah dan atap dak beton. Konservasi ini dilakukan mengingat bagian serambi ini memerlukan adaptasi fungsi berupa penambahan lantai mezanin di atasnya. Konservasi dilakukan dengan merubah sebagian atau beberapa bagian, terutama bagian dalam bangunan untuk menampung fungsi lama dengan persyaratan baru.

\section{Simpulan}

Konservasi merupakan keniscayaan yang harus dilakukan untuk menjaga karakter arsitektur sekaligus mengembangkannya dalam menghadapi konteks 
ruang dan waktu. Konservasi arsitektur berperan dalam menciptakan identitas atau memori suatu kawasan sekaligus menghadirkan konteks kekiniannya. Usaha konservasi pada rancangan arsitektur mensyaratkan adanya kombinasi antara unsur-unsur yang setempat dan unsur-unsur yang pendatang, yang lama dan yang baru tanpa harus menghapuskan atau mengabaikan salah satu unsur.

Pada kasus Masjid Ampel Surabaya, Bangunan masjid lama dan bangunan perluasan di sisi utaranya yang berlanggam kombinasi Jawa Indische Empire. Konservasi di sini dimanfaatkan untuk melestarikan dan mengembalikan kondisi bangunan bersejarah sesuai dengan aslinya. Sementara penambahan bangunan masjid baru yang berlanggam kombinasi Jawa Pan Islamic, dilakukan di kawasan yang dilestarikan, dimana pola bentuknya masih mengacu dan menunjang bangunan lama yang dilestarikan. Sehingga menyerempakkan atau menyandingkan kehadiran antara bangunan lama dan bangunan baru, yang pada kasus ini langgam Jawa dijadikan unsur pengikat yang lama dan yang baru, bisa berlangsung secara selaras.

Pada kasus Masjid Jami' Malang, bangunan utama berupa ruang dalam masjid yang berlanggam kombinasi Jawa-Indische Empire. Konservasi pada masjid ini dimanfaatkan untuk melestarikan dan mengembalikan kondisi bangunan bersejarah sesuai dengan aslinya. Sementara, pada serambi masjid yang berlanggam kombinasi Pan Islamic-Indische Empire, dilakukan perubahan sebagian atau beberapa bagian rancangan serambi dengan tetap mengacu pada langgam awal yang telah ditentukan. Serambi ini selanjutnya berfungsi sebagai selubung yang "menopengi" atau membungkus bangunan utama masjid. Sehingga terjadi pemisahan dalam penghadiran ruang dalam masjid dengan serambi. Dinding berlanggam Indische Empire yang memisahkan kedua bagian bangunan ini berfungsi sebagai pembatas yang tampilan agregatnya selaras dengan dua ruang yang dipisahkannya.

Penjabaran dua karakter arsitektur masjid di atas, masing-masing memberikan keabsahan dalam pembentukan identitas masjid yang berwawasan Nusantara. Keunggulan konservasi pada dua kasus di atas memberi kontribusi mempertemukan "secara dialogis" unsur-unsur yang saling kontradiktif tanpa harus menjadi salah satu di antaranya, dan mengembangkannya menjadi wujud baru yang kaya.

Pada saat ini, konservasi justru harus diletakkan dalam konteks melihat ke depan. Saat ini masyarakat muslim dihadapkan pada kondisi modernitas, dimana kita dihadapkan pada berbagai pilihan yang kita bawa dari masa lalu dengan kemungkinan baru di masa depan. Dengan didasari prinsip universalitas nilai Islam dan kesetempatan lokal, pencarian ekspresi dan 
bentuk arsitektur harus mencerminkan usaha atau ijtihad dalam menafsirkan kondisi modernitas kita.

\section{Daftar Pustaka}

Budihardjo, Eko. 2004. S.O.S Warisan Arsitektur Indonesia Arsitektur dan Kota di Indonesia 5th. Bandung: PT .Alumni.

Hatmoko, Adi Utomo. 1999. Weaving Heritage Sites into Larger Context. Proceeding of International Seminar on Vernacular Settlement. Jakarta: Faculty of Engineering University of Indonesia.

Khan, Hasan ud Din. 1994. An Overview of Contemporary Mosques. Martin Frishman \& Hasan ud-Din Khan (eds.) Mosque: History, Architectural Development and Regional Diversity. London: Thames \& Hudson.

Santosa, Revianto B. 1999. Atap (Masjid Sunan Ampel) dalam Dinamika Arsitektur Masjid Kontemporer Nusantara dalam SNEIDAN 2: Atap Arsitektur Masjid. Surabaya: LSAI. 